Meta

Journal des traducteurs

Translators' Journal

\title{
In Memoriam Elif Daldeniz
}

\section{Yiğit Bener}

Volume 59, numéro 1, avril 2014

URI : https://id.erudit.org/iderudit/1026466ar

DOI : https://doi.org/10.7202/1026466ar

Aller au sommaire du numéro

Éditeur(s)

Les Presses de l’Université de Montréal

ISSN

0026-0452 (imprimé)

1492-1421 (numérique)

Découvrir la revue

Citer ce document

Bener, Y. (2014). In Memoriam Elif Daldeniz. Meta, 59(1).

https://doi.org/10.7202/1026466ar d'utilisation que vous pouvez consulter en ligne.

https://apropos.erudit.org/fr/usagers/politique-dutilisation/ 


\title{
In Memoriam Elif Daldeniz
}

\author{
by Yiğit Bener (author and translator)
}

The great poet Behçet Necatigil writes in his poem Paying:

\author{
"[...] One, on his last day, I say \\ Should account for life in a way \\ Like the banks, with credits and debits \\ If he's given more than he's received \\ Contentedly can he pass away"
}

In this respect, we can say that the balance of our friend and colleague Elif Daldeniz Baysan, who passed away on September 15, 2012, was marked by excessive giving.

Elif was a graceful, and most of all loving, joyful person. Her modest attitude despite her impressive intellectual background, her unbiased approach towards disagreements, her unflagging effort to understand and her persistent refusal to judge made her an outstanding academic. She was a prolific scholar who, rather than bowing to pedantry, strove for true originality.

The manner in which Elif handled her grave illness and approached her impending death was a true lesson to us all. Every day for a year and a half poison-cummedicine was injected into her body, and she suffered the serious side effects of her treatment, yet not once did she express outrage or even so much as complain. Up until the very last moment she lived her short, too short life fully, as best she could. She remained dignified to the very last, her love for those around her never waning, the smile on her face never fading; and though she struggled to do so, she even got up to join us for a last coffee on our terrace in Heybeliada. In her last days, with hardly the strength to move, she somehow found the energy to complete this article that she had been working on for some time.

And then, with that final stroke of the pen, as if quoting Behçet Necatigil, "It's my way and I go, wait death, I'm coming," she left us.

We took her body to the Heybeliada cemetery and covered her with her beloved bougainvilleas from our garden, like Necatigil's poem, In love:

\author{
"[...] You thought your time was vast \\ And it indecent to speak your love in a rush. \\ Never to your mind did it occur \\ That the years would pass by in such haste. \\ In your hidden patch \\ There were blossoms, \\ Budding at night, alone. \\ Too few to give away. \\ Or simply, there wasn't time.
}

(Translated by Candan Baysan and Amy Spangler) 